\title{
CHARACTERIZATION OF AQUIFERS IN PARTS OF ABIA STATE, SOUTHEASTERN NIGERIA
}

\author{
Abija, F.A ${ }^{1,2}$, Nwankwoala, H.O ${ }^{2}$ \\ ${ }^{1}$ Centre for Geomechanics, Energy and Environmental Sustainability (Igees), Port Harcourt \\ ${ }^{2}$ Department of Geology, University of Port Harcourt, Port Harcourt, Nigeria \\ *Corresponding author email: nwankwoala_ho@yahoo.com
}

This is an open access article distributed under the Creative Commons Attribution License, which permits unrestricted use, distribution, and reproduction in any medium, provided the original work is properly cited

\section{ARTICLE DETAILS}

\section{Article History:}

Received 12 November 2017 Accepted 12 December 2017 Available online 1 January 2018

\section{ABSTRACT}

This study was carried out to map and characterize the water bearing formations (aquifers) in Abia State, southeastern Nigeria. Aquifer hydraulic properties were obtained from existing borehole logs and pumping tests data obtained from the field. More recent productive boreholes in the study area were accurately geo-referenced by taking GPS elevations and coordinates. A synergy of all data collected during field visits and those gleaned from the literature, and the geologic information available were analyzed and interpreted to meet the broad framework and specific objectives of this study. Vertical electrical resistivity depth sounding for inferring the resistivity and thicknesses of the vertical succession of different conducting zones in the subsurface was employed in characterization of the subsurface auriferous units. The depth of the boreholes drilled varies from $21.02 \mathrm{~m}-250 \mathrm{~m}$, while the static water level (SWL) varies between $4.57 \mathrm{~m}$ around Ukwa-West to about $35.97 \mathrm{~m}$ around Aba South. The depth range of $9.15 \mathrm{~m}$ to $53.05 \mathrm{~m}$ to the auriferous zone for Umuahia Local Government Area is in agreement with the value of $35.0 \mathrm{~m}$. Very productive aquifers in Abia State are limited to the alluvial deposits and the Coastal Plain Sands lithologies comprising: fine, medium and coarse-grained and often pebbly sands with some intercalations of clays. The alluvium occurs mainly in Ukwa West and East Local Government Areas. Drilling depths in this aquifer range from 30 to $140 \mathrm{~m}$. Prolific production is expected from this alluvium which has an approximate permeability of $35 \mathrm{~m} 2 /$ day. The High production rate (Permeability $=35 \mathrm{~m} 2 /$ day) is expected in the Coastal Plain Sands sediments found in all Local Government Areas stretching south of Umuahia and Bende. Drilling depths ranging from 40 to $250 \mathrm{~m}$ are recommended for boreholes in these LGAs. However, more precise drilling depths must be confirmed by hydro-geophysical site survey, because the geology of Abia State becomes more complicated north of Umuahia and Bende LGAs. This complication in geology affects all other LGAs north of Umuahia.

\section{KEYWORDS}

Aquifers, borehole logs, hydraulic properties, lithology.

\section{INTRODUCTION}

Groundwater forms the most important source of water supply in the urban, sub-urban and rural areas of most Sub-Saharan African (SSA) countries. It therefore drives a country's socio-economic development. Abia State, a component part of Nigeria, a Sub-Saharan country can also derive its socio-economic activities from the sustainable development of available groundwater in the area. Profitable groundwater everywhere in the world exists in the sub-surface geologic material known as the aquifer. Since it exists below the earth's surface and is not visible to anybody, its occurrence, movement, flow direction and other attributes are poorly understood by most people. Consequently, groundwater has not been developed to its full potential as a source of high economic activities and good water quality in many parts of Abia State [1]. Rapid urban expansion has often resulted in increased risk to groundwater quality in areas of recharge. In the past several decades, climate change has resulted in unpredictable rainfall events. This generally affects groundwater recharge quality and quantity negatively and also controls available surface water. All these create enormous challenges and pose threats to groundwater, and consequently affect continued provision of adequate and safe potable water for present and future generations of people everywhere on the planet earth. Abia State is not excluded from such negative impacts. The mapping and characterization of aquifers in Abia State at a time like this, has therefore become necessary so that adequate planning to ensure continued economic activities through sustainability of groundwater. It is anticipated that this process will bring about unprecedented socio-economic progress and continued supply of safe potable water now and in the future.

\section{LOCATION/DESCRIPTION OF THE STUDY AREA}

The study area, Abia State is located in the south-eastern part of Nigeria (Figure 1). The State is known for its commercial activities centered at Aba, which was formerly a British Colonial Government outpost. The entire state lies approximately between latitudes $4^{\circ} 48^{\prime} \mathrm{N}$ and $6^{\circ} 02^{\prime} \mathrm{N}$ and

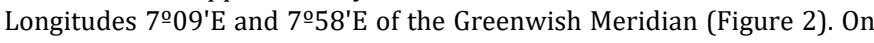
the north and the northeast, the state is bounded by Enugu and Ebonyi states respectively. The eastern boundary is occupied by the Cross-River State, while the southeast border is shared by Akwa Ibom State. Rivers State occupies the southern and southwest boundaries. The western and northwest borders are occupied by Imo and Anambra States respectively. The entire State is divided into seventeen (17) administrative units called Local Government Authorities (LGAs) (Figure 2).

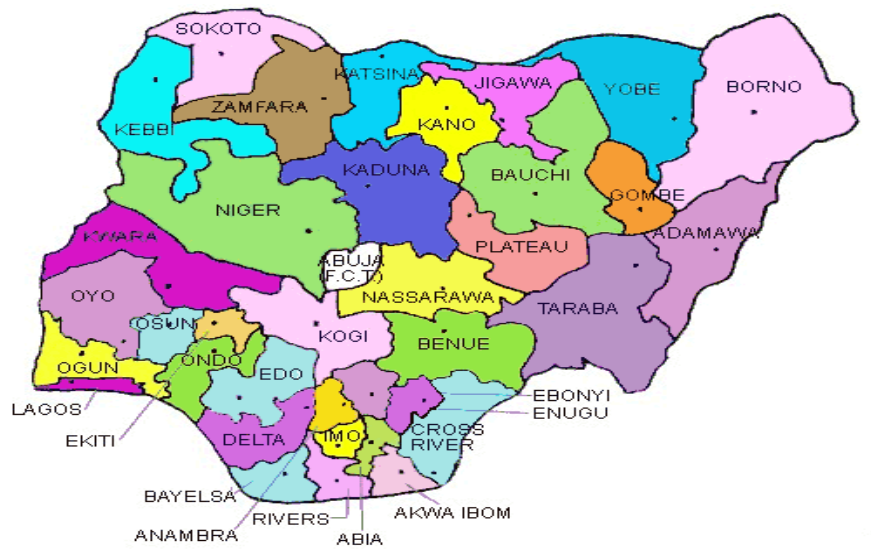

Figure 1: Map of Nigeria showing the study area (Abia State) 


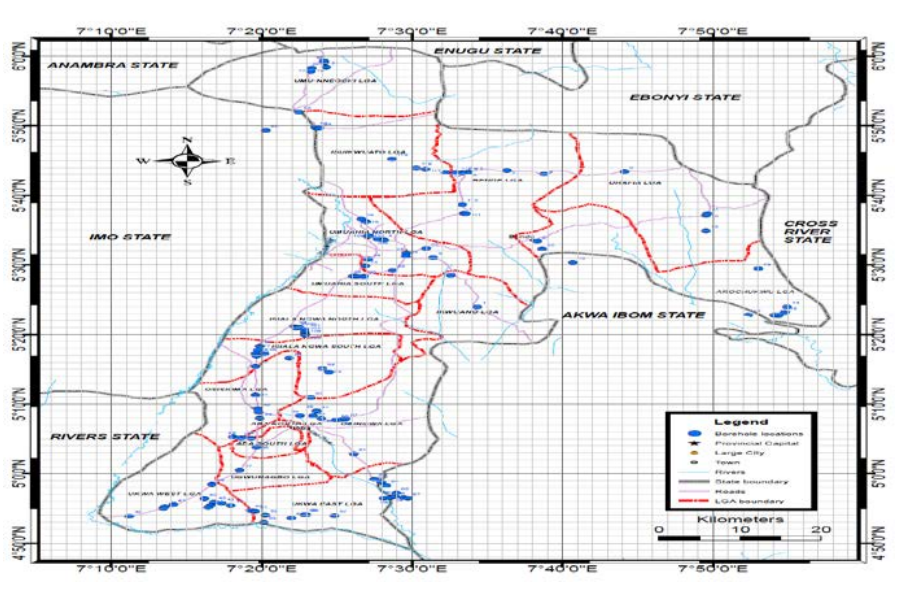

Figure 2: Map of Abia State showing the Local Governments Areas and some borehole locations

The physiographic information on Abia State reveals that the climate of the area falls within the equatorial climatic belt with alternating dry and wet seasons [2]. The wet season starts from March and ends around October, while the dry season spans between November and February each year. The seasonal variation in the climate of the state is caused by the northeast trade wind that blows across the Sahara Desert and the southerly humid marine air mass that blows across the Atlantic Ocean. The annual rainfall is between $2000 \mathrm{~mm}$ and $2250 \mathrm{~mm}$ in the south, and between 1250 and $2000 \mathrm{~mm}$ in the northern part of Abia [2].

The topography in the southern part of the state is low-lying while the other parts of the state have moderately high plains with elevations ranging between 20 and 200 metres above sea level (Figure 3). The vegetation of the area is that of the rainforest comprising various species of shrubs and high forest trees all over the area - both within the hilly and depressed areas.

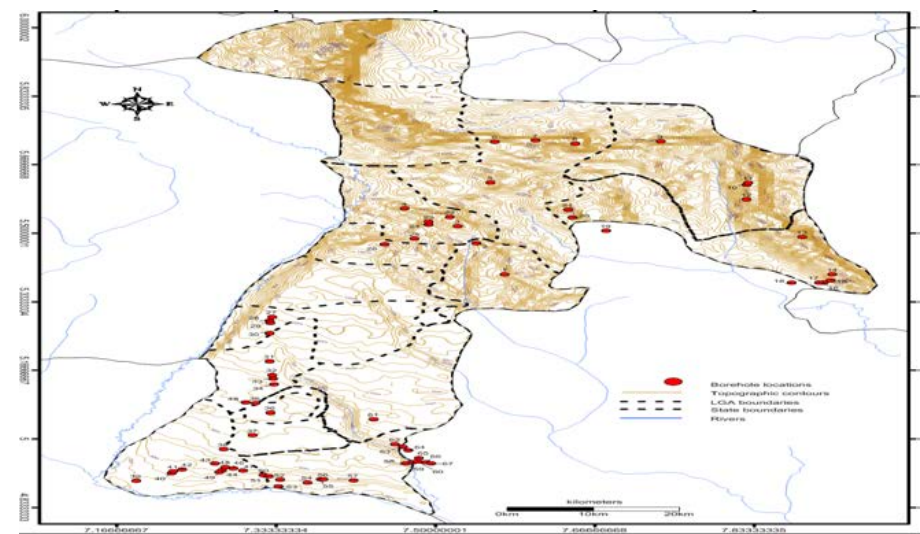

Figure 3: Topographic Map of Abia State showing relief, drainage and some borehole locations

Geologically, Abia State is located within the transition zone of the Benin and Ogwashi-Asaba Formations of the coastal sedimentary rocks of the northern Niger Delta. Therefore, the major geologic sequences encountered in the area include the Coastal Plain Sands otherwise known as Benin Formation, the Ogwashi-Asaba and Bende-Ameki Formations (Figure 4). These lithologies are underlain by the Paleocene Imo shales which are conspicuous in the northern part of the study area. The Benin Formation (Late Tetiary-Early Quaternary age) is the most predominant and it is overlain by the Recent Alluvium and underlain by the OgwashiAsaba Formation. The Benin Formation is about 200m thick and the lithology is unconsolidated fine-medium-coarse-grained, cross bedded sands occasionally pebbly with localized clays and shales [3,4]. Most of the aquifers in the study area tap from this formation. The yield is prolific. The Ogwashi-Asaba Formation is made up of variable succession of clays, sands and grits with seams of lignite. It is directly underlain by the BendeAmeki Formation.

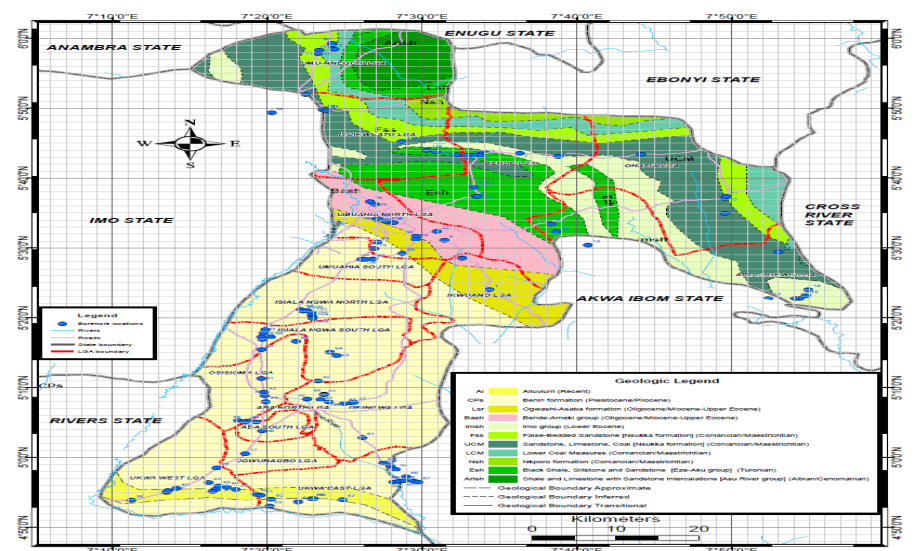

Figure 4: Geologic Map of Abia State showing LGA boundaries and some boreholes

\section{METHODS OF STUDY}

The materials used in the execution of this project include the location map (Figure 2) which was divided into grids to enable the proper planning and execution of the exercise. The approach for aquifer mapping in the area was carried out systematically, from one Local Government to the other. At every borehole site, the coordinates of the location were taken using a Geographical Positioning System (GPS) and recorded in the field notebook. Detailed information such as the yield, age of the borehole as well as the name of the community/village where the water project is situated was equally obtained from individuals and from public sign post describing the project and locations (Table 1).

Two methods of aquifer characterization the geolectrical method which is a well-known and established method of surface, non-invasive and quantitative geophysical technique of evaluating and locating subsurface aquiferous zones employing vertical electrical resistivity depth sounding called the Schlumberger array adopted by some study in aquifer characterization in Bayelsa and Rivers states respectively and characterization of aquifer hydraulic characteristics based on a study nonequilibrium graphical method of pumping test analysis also implemented in a Nigerian basin were adopted for this study based on availability of equipment and interpretive software [5-8].

Lithologic logs and pumping test results for representative boreholes were obtained from the Anambra Imo River Basin Authority and supplemented with field pumping test results in few locations for study. The boreholes were chosen on account of availability of lithologic logs and pumping test results. Supplementary geological and hydrogeological information were obtained from available maps and records of hand dug wells. The logs enabled the establishment of the subsurface stratification, casing and screen positions, static water levels and aquifer textural properties while the aquifer pumping test data for each borehole comprised 1 to 3 stage step-drawdown tests, single stage and recovery measurements. These were used to determine aquifer hydraulic properties such as transmissivity (T), hydraulic conductivity $(\mathrm{K})$ and specific capacity (Cs). Pumping test data analysis was based on a study non-equilibrium graphical method [7]. This method has been found suitable where the abstraction well itself serves as the observation well. By this method, the transmissivity (T) is given by:

$\mathrm{T}$

$$
=\underline{2.303 Q_{\mathrm{s}}}
$$

\section{$4 \pi \Delta S$}

Where $\mathrm{Q}=$ discharge or yield $\left(\mathrm{m}^{3} / \mathrm{sec}\right)$.

$\Delta \mathrm{S}=$ change in drawdown over one log cycle.

This formula is useful because some of the boreholes are confined while others are semi-confined. The average drawdown for the twelve boreholes is about $20.41 \mathrm{~m}$. The hydraulic conductivity $(\mathrm{K})$ was calculated from:

$\mathrm{K} \quad=\frac{\mathrm{T}}{\mathrm{b}}$

Where $\mathrm{T}=$ as in (1) above

$\mathrm{B}=$ aquifer thickness (equivalent to the total screen length).

The specific capacity (Cs), a measure of well productivity, was computed from: 


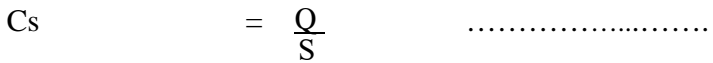

Where $Q=$ as in (1) above

$\mathrm{S}=$ maximum drawdown [8].

Water level measurements for boreholes within the study area were obtained from pumping test records of the boreholes. Water level data employed for this work and depths of boreholes drilled in different parts of the state are presented in Table 2.

\section{RESULTS AND DISCUSSION}

\subsection{Aquifer Hydraulic Characteristics}

Results of lithologic logs carefully studied to delineate the water-bearing sections of the subsurface soil sequence show hydro-stratigraphic units in the study area to be coastal plain sands, alluvial deposits, shaley sandstones and fracture sets. These constitute the distinct aquifer units of the area. The overburdens of the basement areas are characteristically clayey and pebbly, with the clay forming the matrix. Table 1 shows the summary of aquifers and characteristics. Borehole properties in terms of depth, screen intervals (assumed aquifer thickness), static and dynamic water levels, drawdown and yield together with the aquifer constants $\mathrm{T}, \mathrm{K}$ and Cs obtained from the Cooper- Jacob methods are presented in Table 2. In order to derive aquifer constants, curves of drawdown against time were constructed using the pumping test results. In general, results from the recovery method seem more reliable since the recovery data represent in-situ aquifer conditions, and they are free from the effects of pumping and interference (mainly human errors). From Table 3 , transmissivity values range from $2.05 \mathrm{~m} 2 / \mathrm{sec}$ to $9.10 \mathrm{~m} 2 / \mathrm{sec}$ and 0.24 $\mathrm{m} 2 / \mathrm{sec}-4.17 \mathrm{~m} 2 / \mathrm{sec}$ in the southern Niger Delta basin aquifer and Northern Lower Benue Trough aquifers respectively with proportional variations with yields indicative of the permeability in the study area.

The low $\mathrm{T}$ values also imply that it will take a considerable time for the aquifers recharge into wells removed during pumping. Hydraulic conductivity values range from $0.385 \mathrm{~m} / \mathrm{sec}-1.71 \mathrm{~m} / \mathrm{sec}$ in the south and $0.045 \mathrm{~m} / \mathrm{sec}-0.781 \mathrm{~m} / \mathrm{sec}$ in the south and north respectively. The specific capacity values range from $0.053 \mathrm{~m} 3 / \mathrm{sec} / \mathrm{m}-0.26 \mathrm{~m} 3 / \mathrm{sec} / \mathrm{m}$ in the south and $1.03 \times 10-5 \mathrm{~m} 3 / \mathrm{sec} / \mathrm{m}-7.7510-5 \mathrm{~m} 3 / \mathrm{sec} / \mathrm{m}$ in the Lower Benue Trough aquifers. The aquifers may thus be classified on the basis of yield as poor to moderate in the North of the State and Good to excellent in the south according to the classification scheme of Dike (1990). Table 3 is the range of some aquifer parameters for boreholes drilled in some LGAs of Abia State while Table 4 shows drilled boreholes information in the various Local Government Areas of Abia State. The generally low yield in the North is due to the impact of the lithology which is characterized by clay lenses and matrix that occur within the materials of the two aquifer units in the Lower Benue Trough. Since groundwater is the main source of supply in the area and given that the boreholes available are incapable of yielding large water quantities in the North of the State, it implies that more boreholes drilled to specific hydro-geophysical interpreted results supplemented by hand dug wells will be required to augment the shortfalls since increasing population will mean more water demand. Surface water impoundment by earth dams will also increase the quantity of water available for supply. The Southern part of the state however is rich in groundwater supplies and boreholes will always be productive all season. In addition, an efficient water management policy is imperative for sustainable water supply planning.

Table 1: Summary of aquifers and characteristics

\begin{tabular}{|l|l|l|l|l|l|l|}
\hline Basin & Aquifer & Resistivity & Aquifer & Average & Litho- & Prospectively \\
\hline Section & number & $\mathbf{( \Omega m})$ & $\begin{array}{l}\text { thickness } \\
(\mathbf{m})\end{array}$ & $\begin{array}{l}\mathbf{d e p t h} \\
(\mathbf{m})\end{array}$ & composition & \\
\hline $\begin{array}{l}\text { Niger Delta } \\
\text { Basin }\end{array}$ & $1^{\text {st }}$ & 211 & $\begin{array}{l}40- \\
\text { infinity }\end{array}$ & $\begin{array}{l}35- \\
\text { infinity }\end{array}$ & Sands & $\begin{array}{l}\text { Good to } \\
\text { Excellent }\end{array}$ \\
\hline $\begin{array}{l}\text { Transitional } \\
\text { Boundary }\end{array}$ & $1^{\text {st }}$ & 7310 & 35 & 50 & $\begin{array}{l}\text { Shaley } \\
\text { sandstones }\end{array}$ & $\begin{array}{l}\text { Moderate to } \\
\text { Good }\end{array}$ \\
\cline { 2 - 7 } & $2^{\text {nd }}$ & 1620 & Infinite & 120 & $\begin{array}{l}\text { Sands } \\
\text { Eood to } \\
\text { Excellent }\end{array}$ \\
\hline $\begin{array}{l}\text { Lower } \\
\text { Benue } \\
\text { Trough }\end{array}$ & $1^{\text {st }}$ & 440 & $25-32$ & 35 & $\begin{array}{l}\text { Shaley } \\
\text { sandstone }\end{array}$ & Poor to Fair \\
\cline { 2 - 7 } & $2^{\text {nd }}$ & 916 & Infinite & 80 & $\begin{array}{l}\text { Shaley } \\
\text { sandstone }\end{array}$ & $\begin{array}{l}\text { Moderate to } \\
\text { Good }\end{array}$ \\
\hline
\end{tabular}

Table 2: Aquifer hydraulic characteristics

\begin{tabular}{|l|l|l|l|l|}
\hline Location & Transmissivity & $\begin{array}{l}\text { Hydraulic } \\
\text { Conductivity }\end{array}$ & $\begin{array}{l}\text { Specific } \\
\text { Storage }\end{array}$ & Remark \\
\hline $\begin{array}{l}\text { Southern basin (Niger Delta } \\
\text { coastal plain sand aquifer }\end{array}$ & $2.05-9.10$ & $0.385-1.71$ & $0,053-0.26$ & \\
\hline Lower Benue Trough & $0.24-4.17$ & $0.045-0.781$ & $\begin{array}{l}1.03 \times 10^{-5}- \\
7.75 \times 10^{-3}\end{array}$ & \\
\hline
\end{tabular}

Table 3: Range of some aquifer parameters for boreholes drilled in some LGAs of Abia State

\begin{tabular}{|c|c|c|c|}
\hline LGA & $\begin{array}{l}\text { Yield } \\
(1 / \mathrm{sec})\end{array}$ & $\begin{array}{l}\text { Range of Transmissivity } \\
\left(\mathrm{m}^{2} / \mathrm{day}\right)\end{array}$ & Source \\
\hline \multicolumn{4}{|c|}{ Northern part of the study area } \\
\hline Arochukwu & $6.81-10.28$ & $13.23-18.26$ & AIRBDA, NGSA and FMWR \\
\hline Bende & $0.31-12.64$ & $0.36-13.04$ & AIRBDA, NGSA and FMWR \\
\hline Isuikwato & $1.1-56.88$ & $0.24-97.75$ & AIRBDA and FMWR \\
\hline Ohafia & $6.11-26.39$ & $0.18-55.68$ & AIRBDA \\
\hline \multicolumn{4}{|c|}{ Southern part of the study area } \\
\hline Aba North & $19.33-31.25$ & $13.44-23.40$ & AIRBDA \\
\hline Aba South & $2.50-57.02$ & $12.50-238.05$ & AIRBDA, NGSA and FMWR \\
\hline Isiala Ngwa North & $10.3-12.92$ & $5.20-162.50$ & AIRBDA and NGSA \\
\hline Isiala Ngwa South & $12.22-71.67$ & $5.10-356.14$ & AIRBDA and NGSA \\
\hline Ukwa West & $12.11-61.25$ & $5.44-326.8$ & AIRBDA \\
\hline Ukwa East & $12.97-64.44$ & $6.53-484.19$ & AIRBDA and NGSA \\
\hline Umuahia & $1.26-51.38$ & $1.33-51.47$ & AIRBDA \\
\hline
\end{tabular}

AIRBDA = Anambra Imo River Basin Development Authority; NGSA = Nigeria Geological Survey Agency; FMWR = Federal Ministry of Water Resources

A detailed examination of the geologic map of Abia State (Figure 4) clearly showed the distribution of aquifers in the area under study. All Local Government Areas underlain by formations such as the Recent Alluvium in Ukwa East and Ukwa West; and all LGAs underlain by the Benin Formation, such as Ukwa East, Ukwa West, Obingwa, Aba (North and South), Isiala Ngwa (North and South), Osisioma and Umuahia (North and South), have aquifers with fairly high permeability of about $35 \mathrm{~m} 2 /$ day. Local Government Areas such as Ikwano, Central parts of Umuahia (North and South) and eastern-most part of Umuahia South, are underlain by the Ogwashi-Asaba Formation with a moderate permeability of $5 \mathrm{~m} 2$ /day. Aquifers within the Bende-Ameki Formation stretched through the southwesternmost part of Isiukwato, run in a generally NW-SE orientation through central Umuahia South and the southern part of Bende LGA and go through northernmost portion of Ikwano LGA, all have an average permeability value of $10 \mathrm{~m} 2$ /day. Productivity from all such formations as the Bende-Ameki and Ogwashi-Asaba will be moderate.

Moderate productivity due to permeability value of $5 \mathrm{~m} 2$ /day is expected from the False-Bedded Sandstone (Nsukka Formation) which underlie a narrow N-S portion of Umu-neochi, NW Isiukwato and the E-W portions of Bende and Ohafia LGAs. A very good permeability of $50 \mathrm{~m} 2 /$ day is expected by some lenticular portions of the friable Ajali Formation (Upper Coal Measures). This aquiferous formation occurs N-S in Umu-neochi, runs NWSE through Isiukwato, and is bifurcated by the impermeable Imo Shale Group and Eze-Aku Shales. The upper limb of this bifurcation goes through Bende LGA and broadens N-S across Ohafia and Arochukwu LGAs (Figure 4). All other formations such as the Lower Coal Measures, Nkporo Shales Eze-Aku Shales and the Asu River Group have no hydrogeologic significance. They are found in the northern LGAs of Abia State, where only very deep boreholes can meet low to moderate productive aquifers. This again proves the deterministic control of geology. Figure 5 to figures 13 shows the drawdone curves for the various locations while figure 14 is the geologic framework model.

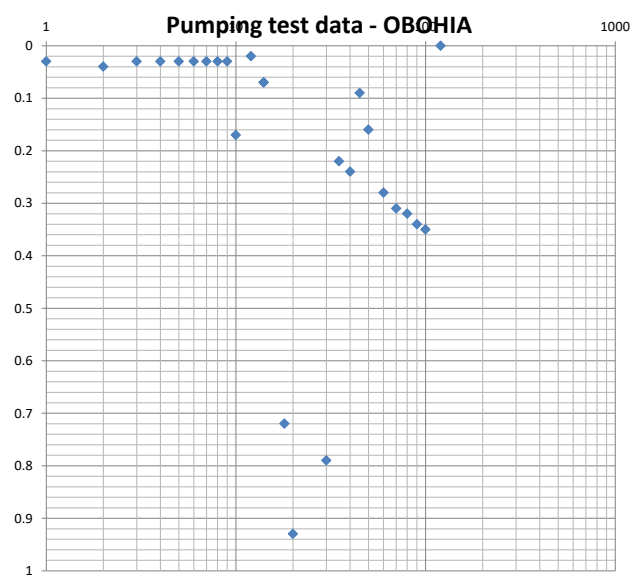

Figure 5: Time - drawdown curve of Obohia, typical Niger Delta basin aquifer in Abia south. 
Time drawdown curve, Obohia

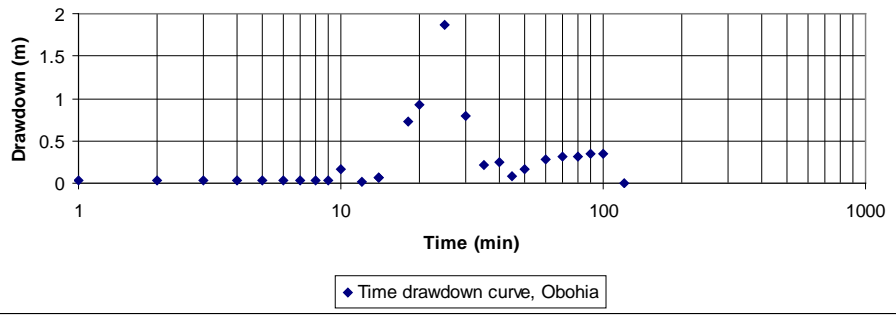

Figure 6: Time - drawdown curve of Obohia-2, typical Niger Delta basin aquifer in Abia south.

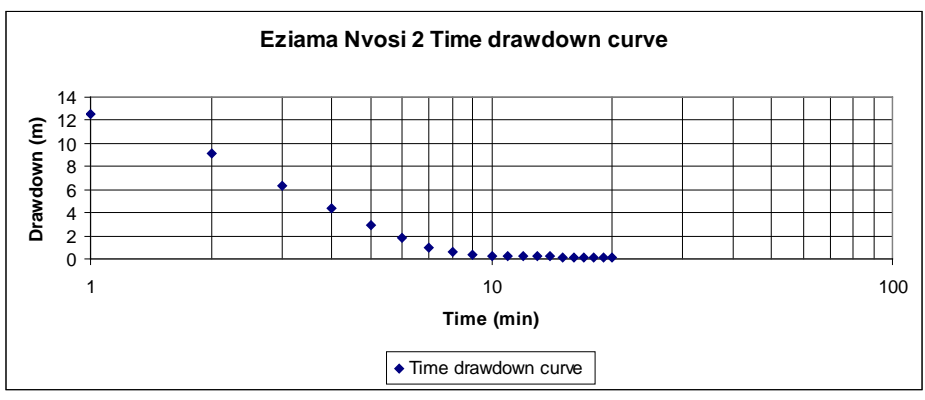

Figure 7: Time - drawdown curve of Eziama-Nvosi, Abia North.

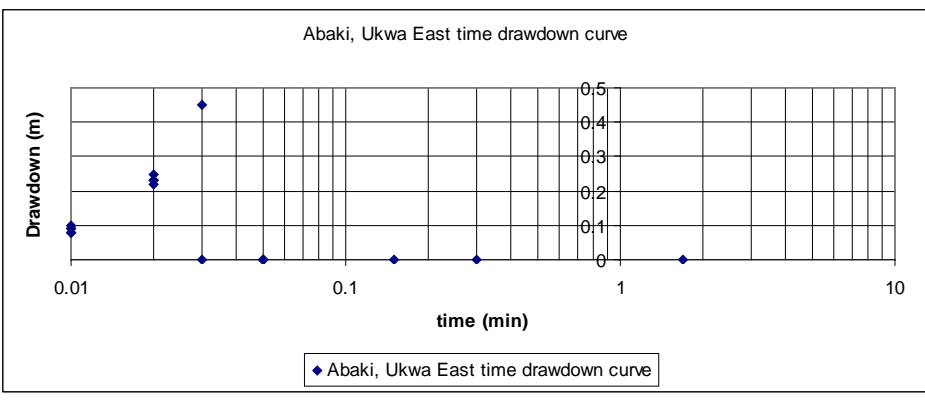

Figure 8: Time - drawdown curve of Abaki typical NGB coastal plain sand aquifer, Abia South.

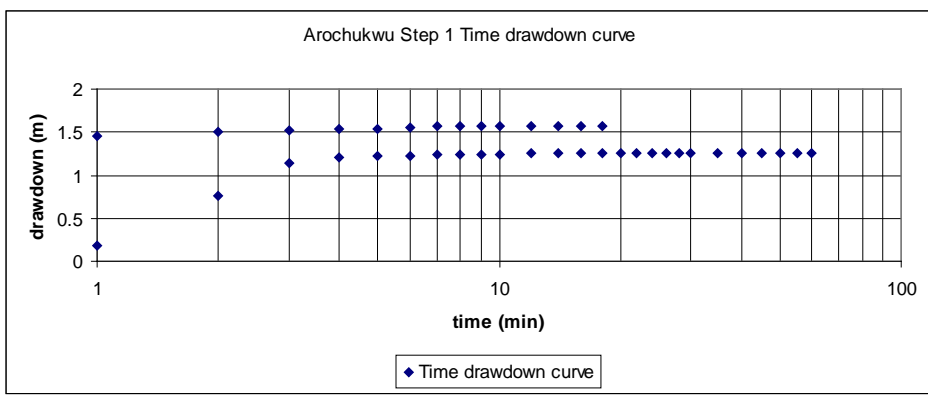

Figure 9: Time - drawdown curve of Arochukwu typical Lower Benue Trough shaley sandstone aquifer, Abia North.

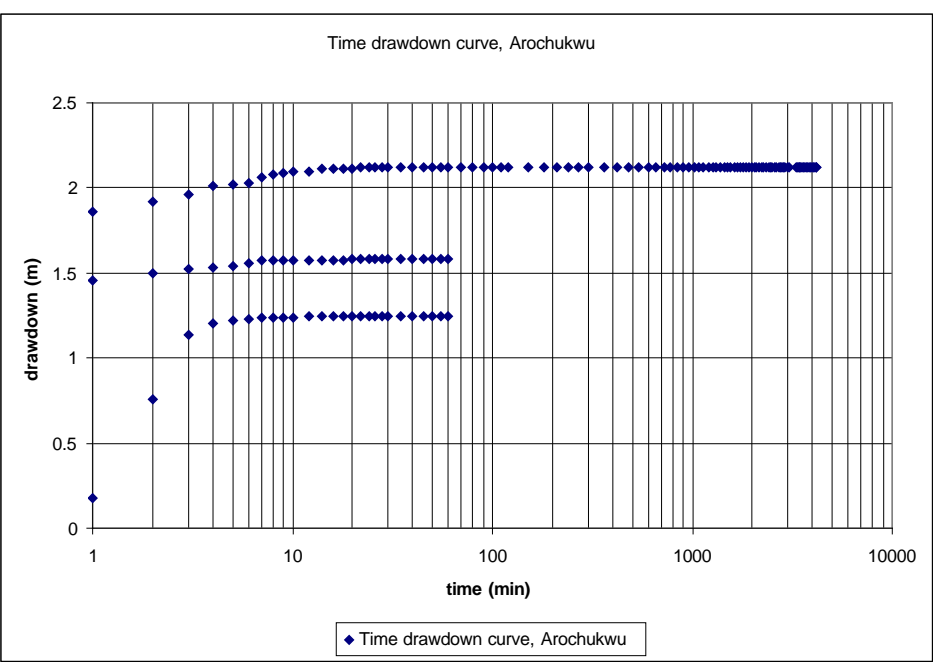

Figure 10: Time - drawdown curve of Arochukwu-2 typical Lower Benue Trough shaley sandstone aquifer, Abia North.
Olokoro time drawdown curve

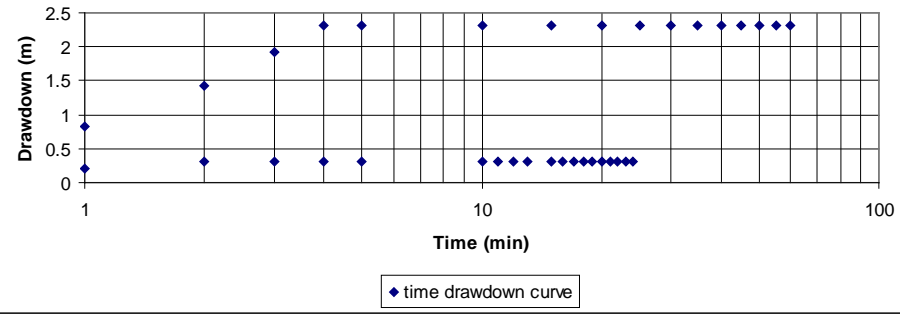

Figure 11: Time - drawdown curve of Olokoro, Umuahia typical NGB Lower Benue Trough transitional boundary aquifer.

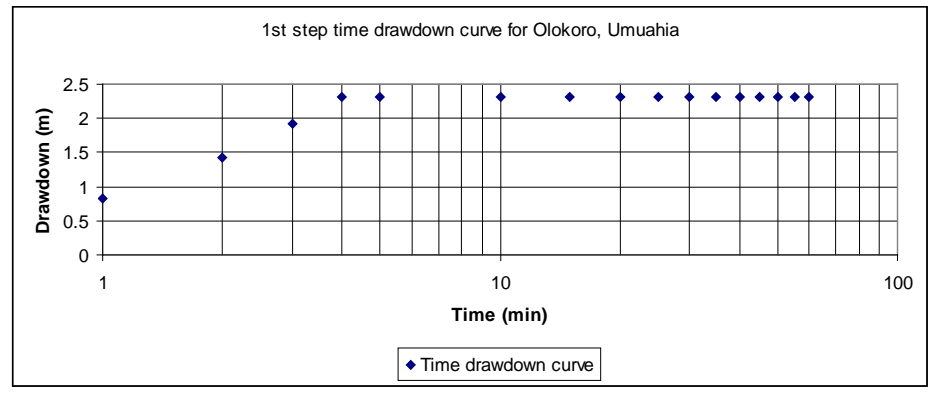

Figure 12: Time - drawdown curve of Olokoro-2, Umuahia typical NGB Lower Benue Trough transitional boundary aquifer.

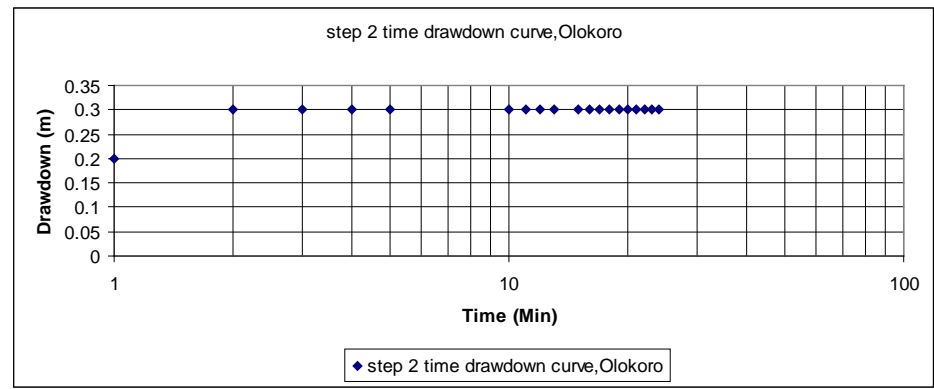

Figure 13: Time - drawdown curve of Olokoro-3, Umuahia typical NGB Lower Benue Trough transitional boundary aquifer.

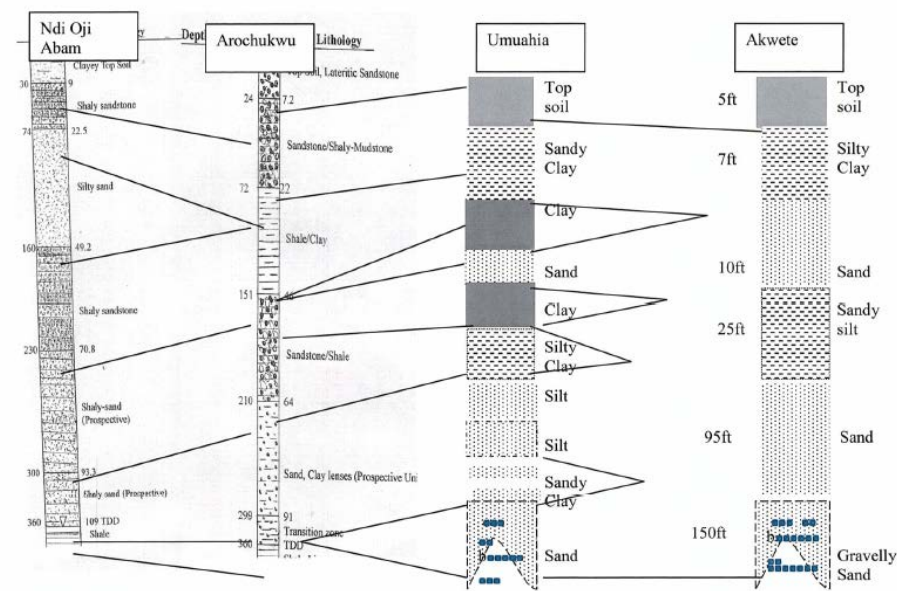

Figure 14: Aquifer geoelectric framework model correlation across the Lower Benue Trough, transitional boundary and Niger Delta basins.

Table 4: Drilled boreholes information in the various Local Government Areas of Abia State 
Earth Sciences Pakistan (ESP) 2(1) (2018) 18-22

\begin{tabular}{|c|c|c|c|c|}
\hline LGA & SWL Range & \begin{tabular}{|c|} 
Borehole \\
Drilled Depth \\
Range
\end{tabular} & Lithology & Source \\
\hline Aba North & 29.86-30.45 & $75-90$ & CPS & AIRBDA \\
\hline Aba South & $18.25-35.97$ & 21.02-183 & CPS & $\begin{array}{l}\text { AIRBDA, NGSA } \\
\text { and FMWR }\end{array}$ \\
\hline Arochukwu & $15.25-132.0$ & $90-249$ & $\begin{array}{l}\text { False Bedded Sandstone, } \\
\text { Lower Coal Measure and } \\
\text { Imo-Shale Group }\end{array}$ & $\begin{array}{l}\text { AIRBDA, NGSA } \\
\text { and FMWR }\end{array}$ \\
\hline Bende & $10.5-34.45$ & $60.69-249$ & $\begin{array}{l}\text { Bende-Ameki group, Upper } \\
\text { Coal Measures and Imo-Shale } \\
\text { Group }\end{array}$ & $\begin{array}{l}\text { AIRBDA, NGSA } \\
\text { and FMWR }\end{array}$ \\
\hline $\begin{array}{ll}\text { Isiala } & \text { Ngwa } \\
\text { North } & \\
\end{array}$ & $19.0-97.50$ & $82.93-153.3$ & CPS & $\begin{array}{ll}\text { AIRBDA } & \text { and } \\
\text { NGSA } & \\
\end{array}$ \\
\hline $\begin{array}{ll}\text { Isiala } & \text { Ngwa } \\
\text { South } & \end{array}$ & $23.70-50.52$ & $64.40-91.46$ & CPS & $\begin{array}{l}\text { AIRBDA and } \\
\text { NGSA }\end{array}$ \\
\hline Isuikwato & $19.0-115.20$ & $152.40-243.8$ & $\begin{array}{l}\text { Asu River Group, False- } \\
\text { Bedded Sandstone, Eze-Aku } \\
\text { shale and CPS }\end{array}$ & $\begin{array}{l}\text { AIRBDA and } \\
\text { FMWR }\end{array}$ \\
\hline Umu-Nneochi & $97.0-115.2$ & $180-195$ & Asu River Group, Eze-Aku & \\
\hline Obioma Ngwa & $17.7-36.0$ & $63.11-147.0$ & CPS & AIRBDA \\
\hline Ohafia & $13.6-81.65$ & $115.80-255.0$ & $\begin{array}{l}\text { Upper and lower Coal } \\
\text { Measures, Eze-Aku shale, } \\
\text { False-Bedded Sandstone and } \\
\text { Asu-River group }\end{array}$ & AIRBDA \\
\hline Ikwuano & $43.0-46.3$ & $150-183.0$ & $\begin{array}{l}\text { Ugwashi-Asaba formation and } \\
\text { CPS }\end{array}$ & Not stated \\
\hline Ukwa West & $7.8-26.52$ & $143-200$ & CPS & AIRBDA \\
\hline Ukwa East & $4.57-19.20$ & $38.10-125.4$ & CPS & $\begin{array}{l}\text { AIRBDA and } \\
\text { NGSA }\end{array}$ \\
\hline Umuahia & $9.15-53.05$ & $15.2-198.0$ & $\begin{array}{l}\text { CPS, Bende-Ameki group and } \\
\text { Lignite Formation }\end{array}$ & AIRBDA \\
\hline
\end{tabular}

\section{REFERENCES}

[1] Abija, F.A., Harry, I. M., Udom, G. J. 2016. Integration of vertical electrical sounding and 2D electrical tomography in the delineation of saltwater/freshwater interface in parts of Rivers State. 52nd NMGS conference paper.

[2] Cooper, H.H., Jacob, C.E. 1946. A generalized graphical method for evaluating formation constants and summarizing well-field history. Trans America Geophysical Union, 27, 526-534.

[3] Chukwudi, C.E., Ugwu, G.Z., Austin, O., Okamkpa, J. 2013. Using the relationships between geoelectrical and hydrogeological parameters to assess aquifer productivity in Udi LGA, Enugu State, Nigeria. Journal of Geology and Mining, 3 (1), 9-18.

[4] Ebilah-Salmon and Partners. 1993. In Association with Esokay Ltd, Abia State Rural Water Supply Project, Feasibility Report and Preliminary Engineering Design Report, 183.

[5] Ebilah-Salmon and Partners. 1994. Investigation of the Existing Water Supply Facility Within the University Complex. Geophysical Report and Recommendations for Reactivation and Future Exploration for Potable Water Supply. Federal University of Agriculture, Umudike, 25.

[6] Igboekwe, M.U. 2005. Geoelectrical Exploration for Groundwater Potential in Abia Satate, Nigeria. Ph.D Dessertation, Micheal Okpara University of Agriculture, Umudike, 183.

$\mathrm{CPC}=$ Coastal Plain Sands; SWL $=$ Static Water Level; Drilled Depth and Static Water level are given in meter (m) AIRBDA = Anambra Imo River Basin Development Authority; NGSA = Nigeria Geological Survey Agency; FMWR $=$ Federal Ministry of Water Resources

\section{CONCLUSIONS}

This study revealed that the very productive aquifers in Abia State are limited to the alluvial deposits and the Coastal Plain Sands lithologies comprising fine, medium and coarse-grained and often pebbly sands with some intercalations of clays. The alluvium occurs mainly in Ukwa West and East Local Government Areas. Drilling depths in this aquifer range from 30 to $140 \mathrm{~m}$. Prolific production is expected from this alluvium which has an approximate permeability of $35 \mathrm{~m} 2 /$ day.

The High production rate (Permeability $=35 \mathrm{~m} 2 /$ day) is expected in the Coastal Plain Sands sediments found in all Local Government Areas stretching south of Umuahia and Bende. Drilling depths ranging from 40 to $250 \mathrm{~m}$ are recommended for boreholes in these LGAs. However, more precise drilling depths must be confirmed by-hydro geophysical site survey, because the geology of Abia State becomes more complicated north of Umuahia and Bende LGAs. This complication in geology affects all other LGAs north of Umuahia.

Deep boreholes which encounter Nsukka and Ajali Formations (False Bedded Sandstones and the Upper Coal Measures) are sure to be productive. Prolific production from the Ajali Formation with permeability of $50 \mathrm{~m} 2 /$ day derives from artesian conditions and the friable, poorly sorted lithology with the shales of the False Bedded sandstones on top and the impervious sediments of the underlying Lower Coal Measures with extremely low permeability, providing useful sandwich for confining conditions. Drilling depth in the range of 250 to $300 \mathrm{~m}$ to encounter Nsukka and Ajali Formations are sure to produce well. The range is caused by different rates of erosion. It will be necessary to depend on hydro-geophysical site study to limit this drilling depth range.

[7] Igboekwe, M.U., Nwankwo, C.N. 2011. Geostatistical Correlation of Aquifer Potential in Abia State, South-Eastern Nigeria. International Journal of Geosciences, 2, 541-548.

[8] Igboekwe, M.U., Okwueze, E.E., Okereke, C.S. 2006. Delineation of Potential Aquifer Zones from Geoelectric Sounding in Kwa Ibo River Watershed, Southeastern Nigeria. Journal of Engineering and Applied Sciences, 1 (4), 410-421.

[9] Mbonu, P.D.C., Ebeniro, J.O., Ofoegbu, C.O., Ekine, A.S. 1991. Geoelectric Sounding for the Determination of Aquifer Characteristics in Parts of the Umuahia Area of Nigeria. Geophysics, 56 (2), $284 \quad-291$. doi:10.1190/1.1443042.

[10] Oborie, E., Udom, G.J., Nwankwoala, H.O. 2014. Characterization of aquifers in Yenagoa and Ogbia areas of Bayelsa State, Nigeria: A geolectrical approach. Advanced Journal of Physical Sciences, 3 (2), 31 - 39.

[11] Offodile, M.E. 1992. An Approach to Groundwater Study and Development in Nigeria. Mecon Services Ltd., Jos, 134 - 137.

[12] Tse, A.C., Amadi, P.A. 2009. Hydraulic properties from pumping tests data of aquifers in Azare area, North Eastern Nigeria. Journal of Applied Sciences and Environmental Management, 12 (4), 67-78.

[13] Ukandu, J.S., Udom, G.J., Nwankwoala, H.O. 2011. Aspects of the Hydrogeology of Umuahia South Local Government Area, Abia State, Nigeria. E3 Journal of Environmental Research and Management, 2 (2), $014-026$ 